\title{
LAS FUNCIONES PROCESALES DEL SECRETARIO EN LA NUEVA OFICINA JUDICIAL: CONSTITUCIONALIDAD, EFECTIVIDAD/EFICIENCIA Y TÉCNICA LEGISLATIVA*
}

Manuel Ortells Ramos**

\section{INTRODUCCIÓN}

Las reformas que alteran notablemente una ordenación tradicional suelen contar con defensores proféticos, que sólo nos hacen ver la tierra prometida a la que nos conduce la nueva ordenación, no menos que con detractores que, en aras de conservar una tradición que, aunque mejorable, siguen considerando sustancialmente apreciable, emplean, en ocasiones, artillería con calibres excesivos y no siempre acertada en el ángulo de tiro.

Este trabajo, ${ }^{1}$ destinado a homenajear a mi querida colega Carmina Calvo - dejo para otras partes del libro los merecidos tratamientos académicos, y la menciono como el aprecio personal siempre me ha dictado- ${ }^{2}$ es una aproximación a valorar los cambios normativos recientes en cuanto a las potestades procesales del secretario judicial, cambios razonablemente acompasados al establecimiento de una nueva estructura de apoyo al ejercicio de la potestad jurisdiccional, a la implantación de una nueva oficina judicial. Su principal intención es hacer una valoración equilibrada y que, en cuanto a los posibles defectos, distinga su diferente calidad, desde las posibles perspectivas jurídicas y de política-jurídica con las que las normas pueden ser evaluadas.

\footnotetext{
* Colaboración recibida el 7 de marzo y aprobada el 20 de abril de 2012.

** Catedrático Universidad de Valencia, España. Correo electrónico: manuel.ortells@uv.es.

${ }^{1}$ Este trabajo se ha realizado en el contexto del proyecto de investigación financiado por el Ministerio de Ciencia e Innovación del Gobierno de España (Proyecto DER 2008-03240). Investigador principal: Prof. Dr. José Martín Pastor.

2 Dado que, en esta ocasión, mi trabajo se publica fuera del contexto del libro homenaje al que está destinado, debo precisar que me refiero a la Profesora Doctora Doña María del Carmen Calvo Sánchez que, hasta su reciente jubilación, fue Catedrática de Derecho Procesal de la Universidad de Salamanca.
} 


\section{Problemas de constitucionalidad, sí, pero con mesura}

La Constitución española sentó las bases para tratar, con rigor jurídico, la vinculación entre potestad jurisdiccional y órgano jurisdiccional, al diseñar, con la inevitable vaguedad de un texto constitucional, pero con suficiente definición, los requisitos del órgano y establecer la norma de exclusiva atribución de aquella potestad.

La Constitución incluso proporciona elementos para determinar en qué consiste tal potestad, lo que facilita la comprobación de si el legislador ordinario, al organizar la jurisdicción, resuelve bien la ecuación constitucional que anuda clase de órgano y clase de potestad.

En la doctrina procesal española no han sido abundantes las reflexiones sistemáticas sobre esa vinculación, realizadas desde los parámetros del texto constitucional ${ }^{3}$. No obstante, algunos problemas relacionados con esa vinculación, llegaron a ser planteados incluso antes de que la Constitución estableciera las reglas para resolverlos con criterios diferentes a los, tal vez bien argumentados, pero en ningún caso normativos, criterios de política jurídica. Me refiero, por ejemplo, a los problemas sobre la naturaleza de las potestades del juez respecto de la dirección del proceso, ${ }^{4}$ y a la naturaleza jurídica de la instrucción previa o procedimiento preliminar penal ${ }^{5}$.

\footnotetext{
3 Sin duda se ha dedicado atención a las características del órgano jurisdiccional y a explicar en qué consiste la potestad jurisdiccional, pero con una metodología que considera esas materias como temas de teoría jurídica no condicionada por referentes jurídico-positivos determinados, sino que deben ser tratados desde criterios históricos, de Derecho comparado, de filosofía jurídica o de teoría política. El vacío al que me refiero es al de un análisis de esos temas metodológicamente vinculados a las normas constitucionales - para cuya interpretación, sin duda, han de ser tenidos en cuenta los criterios mencionados-y del que deriven consecuencias para valorar las decisiones del legislador ordinario sobre, por lo que ahora interesa, la atribución constitucionalmente válida de la potestad jurisdiccional. Intenté, hace mucho tiempo, un ensayo en la parte I, capítulo II de mi Memoria sobre el concepto, método y fuentes del Derecho procesal, inédito de 1983, pero presentada en las oposiciones a cátedra de 1984 y de la que hay un ejemplar depositado en la Biblioteca de Ciencias Sociales de la Universidad de Valencia. Más accesibles, aunque sin el aparato bibliográfico de la obra inédita, mis Introducción al Derecho procesal, Editorial Comares, Granada, 1999, pp. 11-96, y "Aproximación al concepto de potestad jurisdiccional en la Constitución española", en Anuario de la Facultad de Derecho de la Universidad de Extremadura, Cáceres, № 3, años 1984-1985, pp. 415-458.

4 Véase, por ejemplo, Ballbé, M., "La esencia del proceso", Revista General de Legislación y Jurisprudencia, 1947, pp. 42-46; Serra Domínguez, M., "La jurisdicción", en Estudios de Derecho Procesal, Barcelona, 1969, pp. 39-40; GutiérRez de Cabiedes, E., "Una nueva reflexión acerca del concepto del Derecho procesal", en Estudios de Derecho Procesal, Pamplona, 1974, pp. 50-51; De LA Oliva Santos, A., "Sobre conceptos básicos del Derecho procesal", en RDProlberoam, 1976, pp. 198-199.

5 Sobre este tema en la bibliografía española no reciente, puede verse: VIADA, C., ArAGOnESES, P., Curso de Derecho procesal penal, I, Madrid, 1971, pp. 254 267, II, Madrid, 1970, pp. 13 15; FENECH, M., Derecho procesal penal, II, Barcelona, 1960, pp. 941 942; AlCAlá ZamORA y CASTILlo, N., "En torno a la noción de proceso preliminar", en Scritti giuridici in onore della Cedam, II, Padova, 1953, pp. 304 314; Pastor López, M., "El sumario: su función y naturaleza jurídica", en RDPro, 1965 I, pp. 61 94;
} 
Vigente el texto constitucional, el legislador ha tardado en acometer reformas modificadoras de las atribuciones tradicionales de los jueces, de modo que la doctrina no ha tenido ocasión de enfrentarse con atribuciones de potestades que parezcan constitucionalmente cuestionables desde la perspectiva de la norma de exclusiva atribución a los jueces de la potestad jurisdiccional ${ }^{6}$.

\section{La legislación orgánica y ordinaria para una nueva oficina judicial y} que atribuye al secretario judicial nuevas potestades sobre la dirección del proceso y sobre otras materias

Una ocasión para reflexionar $-\mathrm{O}$, al menos, para tomar postura- sobre el tema ha venido dada por la atribución de nuevas potestades al secretario judicial, vinculada a la nueva ordenación de la oficina judicial, mediante las reformas legislativas que se iniciaron con la Ley Orgánica No 19/2003, de 23 de diciembre, de modificación de la LOPJ (en adelante la citaremos como LOPJreforma 2003), y que continuaron con la ley $N^{0} 13 / 2009$, de 3 de noviembre, de reforma de la legislación procesal para la implantación de la nueva oficina judicial (en adelante la citaremos como ley No 13/2009), y con la Ley Orgánica $N^{\circ} 1 / 2009$, de la misma fecha (en adelante la citaremos como LO 1/2009), que complementaba la anterior en lo necesario para reformar la LOPJ.

El Ilamado Pacto de Estado para la reforma de la Justicia, que firmaron los partidos políticos mayoritarios el 28 de mayo de 2001, ya establecía, en su punto 10, algunos criterios orientativos: "Se redefinirán las funciones de los Secretarios Judiciales. (...) Se les atribuirá facultades plenas de impulso procesal para desarrollar los trámites en que no sea preceptiva la intervención del Juez. Se potenciarán las funciones de ejecución, realización de bienes...".

La LO No 19/2003 fue la primera plasmación normativa de la nueva distribución de potestades entre juez y secretario judicial en relación con el desarrollo del proceso, principalmente con la nueva redacción del art. 456.1,

Fairen Guillen, V., "La disponibilidad del derecho a la defensa en el sistema acusatorio español", en Temas del ordenamiento procesal, II, Madrid, 1969, pp. 1210 1212, nota 30; SerRa Domínguez, M., "La instrucción de los procesos penal y civil: el sumario" y "El juicio oral", ambos trabajos en Estudios de Derecho Procesal, Barcelona, 1969.

${ }^{6}$ Por no hacer demasiado largas las citas, mencionaré que los problemas se limitaban, por un lado, a atribuciones anteriores a la Constitución y que los administrativistas, también antes del texto constitucional, venían denunciando como excesos de la potestad de autotutela de la Administración pública; por otro, y en esta materia sí que se han ido produciendo novedades legislativas, a la atribución de potestades para el procedimiento preliminar del proceso penal. Sobre lo último, y con información muy completa sobre bibliografía, MARTíN PASTOR, J., El Ministerio Fiscal como director de la investigación oficial en el proceso penal, Publicaciones del Real Colegio de España, Bolonia, 2005, pp. 194-314. 
2 y 3, a) LOPJ ${ }^{7}$. El informe preceptivo del CGPJ sobre el anteproyecto de esa ley, aunque se refirió a que, en la nueva atribución de potestades, el juez no podía ser separado funcionalmente del desarrollo del proceso ${ }^{8}$, no puso en cuestión la constitucionalidad de la atribución que hacía el anteproyecto al secretario judicial; se centró, preferentemente, en los aspectos de -por utilizar una expresión acuñada- "administración de la Administración de justicia" relacionados con la nueva oficina judicial, en los que estaba en juego la asignación y coordinación de competencias del CGPJ, del Gobierno central y de las Comunidades Autónomas.

La ley $N^{\circ} 13 / 2009$, la LO 1/2009, complementaria de la anterior, y los trabajos prelegislativos de las mismas, invitaron, de nuevo, a plantearse el tema.

Sobre el anteproyecto de la primera de esas leyes, el CGPJ emitió un informe, cuyo contenido es más descriptivo que valorativo, y que, en lo que se refiere a la cuestión que nos ocupa, me parece ambiguo. No pone en cuestión de un modo general la concreción que, sobre la base de la reforma de la LOPJ por la LO 19/2003, hace el anteproyecto de la distribución de las funciones sobre la dirección del proceso entre juez y secretario judicial ${ }^{9}$. Sus observaciones críticas se refieren a aspectos específicos y, en algún caso no invocan -ni siquiera indirectamente- la naturaleza de potestad constitucionalmente reservada a los jueces ${ }^{10}$. Sin embargo, sí que hace una advertencia general frente a las posibles lagunas del medio de impugnación que permite el control judicial de las resoluciones del secretario judicial (el llamado recurso de

\footnotetext{
7 Recordemos lo que dicen, porque es básico para contrastarlo con la manera en la que la ley $N^{0} 13 / 2009$ ha completado el diseño inicial de la LOPJ:

"1. El secretario judicial impulsará el proceso en los términos que establecen las Leyes procesales.

2. A tal efecto, dictará las resoluciones necesarias para la tramitación del proceso, salvo aquellas que las Leyes procesales reserven a jueces o tribunales. (...)

3. Los secretarios judiciales cuando así lo prevean las Leyes procesales tendrán competencias en las siguientes materias: a) La ejecución salvo aquellas competencias que exceptúen las Leyes procesales por estar reservadas a jueces y magistrados".

${ }^{8}$ Informe sobre el Anteproyecto de Ley Orgánica de reforma de la Ley Orgánica № 6/1985, del Poder Judicial, 22 de abril de 2003, pp. 35, 39.

9 Informe al Anteproyecto de Ley de reforma de la legislación procesal para la implantación de la nueva oficina judicial, 29 de octubre de 2008, pp. 16-19.

10 Para que el juez o el presidente de órgano colegiado conserven las potestades sobre señalamiento de vistas, se invoca la íntima vinculación a la función judicial y al estatuto judicial (p.24); para lo mismo, en cuanto a la suspensión de vistas, se advierte de la implicación del derecho a un proceso sin dilaciones indebidas y se puntualiza que hay causas de suspensión que el secretario judicial nunca debe poder apreciar, porque sólo el juez puede hacerlo (p.25); las potestades de condena en costas y declaración de responsabilidad, que el art. 730.2 LEC atribuye al secretario, estima que deberían atribuirse al juez, aunque sin racionalizarlo por el carácter jurisdiccional de los objetos resueltos (p. 74).
} 
revisión), dado que las mismas pueden llegar a permitir que haya aspectos del impulso procesal que, en definitiva, escapen de toda posibilidad de control por el juez, lo que es contrario al carácter instrumental de ese impulso respecto de la función (principal) de juzgar ${ }^{11}$.

\section{Las "declaraciones" sobre el proyecto de la ley No 13/2009}

Principalmente en relación con el proyecto de la que llegó a ser ley $N^{\circ} 13 / 2009^{12}$, se hicieron públicas dos declaraciones de sendos grupos de juristas que, frente a la ausencia del tema de la constitucionalidad de la atribución de las potestades atribuidas al secretario judicial en los informes del CGPJ, centraron en ese tema sus principales, y radicalmente enfrentados, argumentos.

La "Declaración de Profesores Universitarios de Derecho Procesal", publicada el 29 de enero de 2009, en Madrid, funda su crítica al proyecto directamente en su inconstitucionalidad por ser contrario a la exclusiva atribución a los jueces y magistrados de la administración de justicia o del ejercicio de la potestad jurisdiccional, "lo que requiere e incluye, por la naturaleza de las cosas, constitucionalmente reconocida en el aptdo. 3 del art. $117 \mathrm{CE}$, dirigir, de principio a fin, los procesos de todo tipo", porque "cualquier proceso constituye una elemental e insoslayable garantía del acierto de la sentencia o de la resolución equivalente, de modo que los jueces no pueden ser situados al final del recorrido procesal o verse ajenos a buena parte de sus incidencias". Esa exclusividad -se dice en la declaración- también es desconocida cuando se sostiene que "la ejecución pase a los Secretarios"13, siendo así que "para el

\footnotetext{
${ }^{11}$ El CGPJ entiende, p. 19, que el "recurso de revisión" -como instrumento de control del juez sobre la actividad de dirección procesal del secretario judicial- "puede resultar insatisfactorio en todos aquellos casos en que no se prevea dicho recurso o que, existiendo, no se ejercite por las partes (cursiva MOR), por lo que la decisión del secretario judicial devendría irrevocable. Una posible solución a estos problemas apunta a que la decisión última corresponda al juez o tribunal, en tanto en cuanto el impulso procesal ha de ser instrumental y estar supeditado a la función principal de juzgar, y el mecanismo para que puedan ejercer de forma efectiva el poder de dirección del proceso que les corresponde, pudiera ser la revisión facultativa de oficio de las resoluciones dictadas por el secretario judicial".

12 Realmente los desarrollos de este proyecto ya estaban en germen en la LOPJ-reforma 2003, en el sentido de que ésta los hacía posibles, si bien es cierto que las remisiones de su texto a las leyes procesales como medida (ulterior a la LOPJ) de las potestades reservadas a los jueces, permitía (y permite, sin modificación de la LOPJ) una especificación distinta, menos o más amplia, del alcance de las potestades del juez y del secretario judicial.

13 Permítaseme anotar, desde ahora, que a los firmantes de la Declaración les parece bien que: "En la denominada ejecución forzosa y cuando se trata de procesos civiles o laborales, el Secretario Judicial puede, sí, desempeñar un papel mayor que en la actualidad". Una cierta intriga me produce que no se mencionen el proceso penal, ni el administrativo. Curiosamente en ambos hay muestras señeras de un régimen de ejecución distinto al exclusivamente dirigido por los jueces: en el penal, la competencia de la Administración penitenciaria judicialmente controlada; en el administrativo, un deber de cumplimien-
} 
inicio y el desarrollo de muchos procesos de ejecución han de dictarse no pocas resoluciones que requieren la autoridad y la potestad específicas sólo conferidas a los Jueces y Magistrados". Por lo demás, el proyecto no sólo habilita al secretario judicial para dictar "resoluciones con eficacia meramente procesal, sino también otras con importantes efectos jurídico-materiales, que trascienden el ámbito procesal". En resumen: negro, sin grises, ni blancos.

La "Declaración de profesionales jurídicos", titulada "Hacia una administración de justicia del siglo XXI, garantista, racional y eficiente para el ciudadano", presta también la mayor atención a la valoración de constitucionalidad de la potestad jurisdiccional exclusivamente atribuible a los jueces, y examina si el proyecto la respeta al especificar tanto las potestades del juez, cuanto las nuevas potestades del secretario judicial. Los argumentos en favor de esa tesis se expresan, en algunos pasajes de la declaración, de manera radical; así cuando se afirma que el "núcleo de la tarea jurisdiccional" es "resolver los conflictos que los ciudadanos les plantean", "establecer por decisión judicial qué derechos y obligaciones tienen en relación con un caso concreto", lo que se hace mediante la determinación en la sentencia "del juicio de hecho y del juicio de derecho para llegar a la correspondiente solución". Si todo quedara aquí, estaríamos en las estrictas antípodas de la primera declaración. Para ésta toda la actividad para llegar hasta la sentencia es jurisdiccional, por ser el ineludible presupuesto de la sentencia, mientras que, para la segunda declaración, sólo la sentencia sería manifestación de potestad jurisdiccional. Sin embargo, en honor a la verdad, lo que se sostiene en esta segunda declaración es más matizado, porque, aquellas afirmaciones van acompañadas de este complemento: "lo que debe entenderse por núcleo básico de la actividad de juzgar es la necesidad de que el juez tenga completa y absoluta inmediación en lo que se refiere al conocimiento de las alegaciones de las partes, a la admisión y práctica de la prueba, y a la elaboración y dictado de la sentencia, pues todo ello es lo que permite decidir el conflicto, elaborar el juicio en hecho y en derecho y plasmarlo en la correspondiente resolución".

Ahora bien, poner al juez -o que el juez se ponga- en las situaciones que le permitirán fundadamente dictar una sentencia, requiere que se realicen una serie de actos que -para los autores de esta declaración: 1) son procesales, aunque no son jurisdiccionales y, por ello, una potestad de esa naturaleza no es necesaria para dirigirlos; 2) el proyecto atribuye competencias sobre los mismos al secretario judicial con un alcance correcto, aunque ampliable sin incurrir en

to de la sentencia, inicialmente por la Administración, aunque bajo control eficaz de los jueces. En mi opinión, si tratamos de valoraciones de constitucionalidad de la potestad jurisdiccional ejecutiva, y no de apreciaciones -importantes, aunque diferentes a los temas de constitucionalidad-sobre la mayor o menor efectividad del régimen de la ejecución, no parece justificado distinguir clases de procesos, porque el constitucional "hacer ejecutar lo juzgado" representa una exigencia igual para todo proceso. 
inconstitucionalidad, y 3) en todo caso, cuenta con la garantía de un control judicial final "sobre la mayoría de las competencias atribuidas a los secretarios judiciales", de modo que el juez no queda marginado del proceso, pues, aunque no tenga la primera palabra, tiene una potestad de control posterior ${ }^{14}$.

Resta, por fin, la postura de los autores de esta declaración acerca del alcance constitucionalmente requerido de la potestad jurisdiccional en el proceso de ejecución. Junto a una manifestación meramente descriptiva del proyecto ${ }^{15}$, encontramos declaraciones -por así decir- "reivindicativas" de más amplias atribuciones al secretario judicial: "no forma parte de la potestad jurisdiccional el hacer ejecutar lo no juzgado previamente, lo que permite que otros cuerpos de funcionarios puedan llevar a cabo actividades y procesos de ejecución no judiciales, basados sobre títulos extrajudiciales. Esto permite sostener que la ejecución de títulos no jurisdiccionales no debe ser necesariamente judicial en ningún aspecto y puede ser atribuida a los secretarios judiciales en su integridad, si se decide acudir a los juzgados y tribunales para lograr esa ejecución".

\section{Una aproximación a los problemas de constitucionalidad}

Los temas de constitucionalidad deben ser tratados con moderación. Ni está justificado marginarlos, o resolverlos con fáciles conclusiones negativas, ni lo está descubrir inconstitucionalidades detrás de cada cambio legislativo -particularmente cuando éste altera notablemente una ordenación tradicional-. La propia Constitución confiere al Poder legislativo un poder de libre configuración normativa que puede moverse en un amplísimo campo de opciones de regulación y que no puede ser reducido a una especie de potestad reglamentaria.

Por otra parte, el planteamiento debe ser analítico, centrado en el examen particular de las diferentes normas y no consistente en generalizadoras valoraciones de conjunto.

Lo dicho advierte de lo prudente que hay que ser al ocuparse de problemas de constitucionalidad de una reforma como la que consideramos que, aunque está fundada en unos criterios generales que pueden ser valorados en cuanto

\footnotetext{
${ }^{14}$ Buena parte de las cuestiones problemáticas están en lo que la síntesis -comprensible en una declaración de este estilo- no permite tratar con más detalle. Pero llamemos ya la atención, en cuanto a la "sedante" garantía del control jurisdiccional de actos previos del secretario judicial, sobre si acaso no se estará deslizando la tesis de que, en esencia, no se lesiona la exclusividad de la potestad jurisdiccional siempre que un juez pueda controlar plenamente actos previos de otro órgano del poder público, de modo que la potestad jurisdiccional sería, en esencia, una potestad de control, no una potestad de decir la primera palabra sobre la actuación del Derecho.

${ }^{15}$ Así cuando dice: "destaca poderosamente la previsión legal de que los secretarios judiciales Ileven a cabo la ejecución de sentencias en general, salvo las competencias concretas que las leyes procesales exceptúen por estar reservadas a jueces y magistrados, así como cualesquiera otras competencias que expresamente se prevean por las leyes procesales".
} 
tales, acaba por proyectarse sobre múltiples piezas de la compleja estructura del proceso.

Por eso prefiero llamar "aproximación" a lo que voy a hacer seguidamente. Se trata de hacer unas "catas" en problemas de constitucionalidad. Las clasificaré en tres grupos, por las razones que se verán.

A) Potestad de decidir sobre el tema de fondo de un proceso, potestad de poner término a un proceso y potestad de juzgar

La potestad jurisdiccional consiste, sin duda, en ser una potestad de juzgar, y ésta -también sin duda, porque, por ahora, debemos conceder que no es tan obvio e indiscutible que la misma se extienda a la adopción de decisiones sobre otras cuestiones- es la potestad de apreciar los fundamentos y de decidir sobre una situación jurídico material litigiosa entre quienes son terceros respecto del juzgador.

La CE establece elementos que justifican que este es uno de los contenidos de la potestad jurisdiccional, como potestad exclusiva, sin que la identificación de esta potestad deba quedar limitada a los supuestos en los que la decisión produce cosa juzgada. Es cierto que el TC concede relevancia a la falta de cosa juzgada para negar que haya una atribución inconstitucional de potestad (jurisdiccional) en supuestos en que las Administraciones públicas pueden decidir sobre relaciones jurídicas, aunque sea dudoso que, al hacerlo, estén ejercitando una potestad de autotutela, porque la Administración no es sujeto de la relación ${ }^{16}$. No obstante, esta orientación de la doctrina jurisprudencial del TC difícilmente podría avalar la constitucionalidad de la atribución a los secretario judicial de potestades de decisión como las mencionadas, porque en este caso faltaría todo soporte de competencias del secretario judicial sobre el que asentar una hipotética potestad de autotutela, sometida a posterior control judicial.

¿Qué regulaciones de las reformas de 2003 y 2009 podrían justificar dudas de constitucionalidad en atención al componente de la potestad jurisdiccional que consideramos en este apartado?

En ningún caso se atribuye al secretario judicial potestad de resolución sobre la pretensión objeto del proceso, ni siquiera cuando las partes hayan realizado actos de disposición sobre la misma ${ }^{17}$. Pero, al amparo de lo dispuesto en el art.

\footnotetext{
${ }^{16}$ Remito a Ortells Ramos, Introducción, cit., pp. 77-98; 11-96; “Aproximación al concepto de potestad jurisdiccional en la Constitución española", cit., pp. 415-458; Prólogo a la monografía de Bellido Penadés, R., La tutela frente a la competencia desleal en el proceso civil, Comares, Granada, 1998, pp. XXI-XXIV; Ortells Ramos et al., Introducción al Derecho Procesal, Aranzadi Thomson Reuters, Cizur Menor, 2010, pp. 118-132.

17 La potestad de resolución continúa correspondiendo al juez en los supuestos de renuncia (art. 20.1 LEC), de allanamiento (art. 21.1 y 2 LEC); también en el de transacción (art. 19.2 LEC), aunque, en este caso, el juez no resuelve sobre el objeto.
} 
456.3.d LOPJ-reforma $2003^{18}$, la ley $N^{\circ} 13 / 2009$ ha atribuido a los secretario judicial potestades que van más allá del impulso y de la tramitación del proceso (que son las mencionadas especialmente en el art. 456.1 y 2 LOPJ-reforma 2003) y autorizan a decidir la terminación de la actividad procesal.

Sin embargo, no todas estas potestades merecen la misma valoración desde el punto de vista de la constitucionalidad de la potestad atribuida.

Hay supuestos en los que el secretario judicial puede resolver la terminación del proceso, sin decidir sobre su objeto, aunque la decisión de finalización pueda dar firmeza a una previa resolución judicial sobre el objeto (p. ej., cuando el secretario judicial declarara la deserción de un recurso). En estos supuestos el secretario judicial ejercita una función esencialmente notarial respecto de la actividad procesal, bien sea constatando que las partes están de acuerdo en que el proceso debe finalizar (art. 20.3 LEC -desistimiento consentido por el demandado-; art. 22.1 LEC -acuerdo de las partes en que ha desaparecido la necesidad de tutela jurisdiccional-) ${ }^{19}$; bien constatando la concurrencia de circunstancias de apreciación muy objetiva que, de acuerdo con la ley, dan lugar a la terminación del proceso (art. 237 LEC -caducidad de la instancia-) o a la extinción de una tutela cautelar que había sido otorgada por el juez, cuando esa extinción viene determinada por la desaparición del vínculo de instrumentalidad (arts. 730, 744.1 y 745 LEC).

La resolución del secretario judicial en estos supuestos no consiste en juzgar porque no versa sobre una relación jurídica material entre personas ajenas al que valora y decide. Es cierto que, si esa resolución fuera errónea, afectaría al derecho a la tutela judicial efectiva y a la prohibición de indefensión, pero la previsión de una impugnación ante el juez (art. 454bis.1 LEC) protege frente a esas posibles violaciones de derechos fundamentales.

En otros supuestos, el secretario judicial sigue sin resolver sobre el objeto del proceso, y ni siquiera decide sobre la terminación de éste, pero, en cambio, se pronuncia sobre relaciones jurídicas entre las partes, relaciones que, si bien tienen sus hechos constitutivos en la actividad procesal y son accesorias del proceso, son de Derecho material. En uno de los supuestos el secretario judicial puede declarar la existencia de responsabilidades por daños y perjuicios (art. 730.2 LEC); en otros supuestos, además de la declaración, puede imponer el cumplimiento de obligaciones entre otras personas, partes en el proceso o no (arts. 375 -indemnización del testigo-, 471, pár. 3, 481.4 y 730 -condenas en

\footnotetext{
18 Recuérdese que ese apartado dispone: "3. Los secretarios judiciales cuando así lo prevean las leyes procesales tendrán competencias en las siguientes materias: (...) d) Cualesquiera otras que expresamente se prevean".

19 Se podría asimilar a estos supuestos - por la causa, no por el efecto- el decreto de suspensión del proceso de declaración, a solicitud concorde de las partes (art. 19.4 LEC).
} 
costas-); en otros, por fin, puede establecer el quantum de las prestaciones que deben ser cumplidas (art. 246.3 y 4 LEC -tasación de las costas-).

Hay otros dos supuestos especialmente llamativos, porque la reforma Ilega a configurar, expresamente, una especie de procedimiento sumario (cuyo resultado no vincula al "juicio ordinario ulterior" -arts. 34.2, párrafo tercero y 35.2, párrafo cuarto LEC-). Se trata de los previstos en los arts. 34 y 35 LEC, en cuyos procedimientos el secretario judicial emite una declaración sobre determinados derechos de los procuradores y los abogados, respectivamente, frente a las partes que les hubieran apoderado o encargado la defensa, determina la cuantía de lo adeudado e impone su cumplimiento al obligado.

Diversas consideraciones pueden minimizar o matizar la importancia de las atribuciones del secretario judicial en los supuestos del párrafo anterior, pero, en esencia, cuando el secretario judicial las ejerce actúa como un tercero que, por imposición legal (no por aceptación derivada de un convenio arbitral), decide sobre relaciones jurídico-materiales entre otros. Es decir, ejerce potestad de juzgar, sin ser juez. Y la posibilidad de una impugnación ante el juez no elimina, en este caso, una inconstitucionalidad que se produce porque, dado el objeto sobre el que versa, el secretario judicial no hubiera debido ni siquiera poder decir la "primera palabra".

\section{B) La potestad de ejecución}

La potestad de juzgar no agota las potestades de las que el órgano jurisdiccional ha de estar investido para dar una tutela efectiva -como debe hacer para satisfacer el derecho reconocido en el art. 24.1 CE-. Para ello puede ser necesaria la potestad de ejecución. La cuestión de si la CE también impone la atribución exclusiva a los órganos jurisdiccionales de la potestad de ejecución tiene una respuesta en principio fácil: el art. 117.3 CE establece que forma parte de la potestad jurisdiccional (por lo tanto, de la potestad exclusiva de los tribunales) la potestad de "hacer ejecutar lo juzgado".

A la hora de precisar en qué consiste esa potestad exclusiva de ejecución se suscitan dos problemas.

En primer lugar ¿Quién debe tener la potestad de ejecución de títulos ejecutivos que no consistan en un previo juicio de los tribunales (por ejemplo, los del art. 517.2.2 $2^{\circ}, 4^{\circ}$ a $\left.8^{\circ} \mathrm{LEC}\right)$ ? Una interpretación pegada a la letra del art. 117.3 CE se atrevería a decir ${ }^{20}$ que si el título ejecutivo no consiste en una previa resolución de un tribunal que imponga un deber de prestación ("lo juzgado"), la Constitución ya no le atribuye en exclusiva al juez la potestad de "hacer(lo) ejecutar" y esta potestad puede ser atribuida, sin riesgo de inconstitucionalidad,

\footnotetext{
${ }^{20}$ Y se ha atrevido a decirlo la "Declaración de profesionales jurídicos": véase el anterior apartado II.2.
} 
a otros órganos del poder público. No comparto esa opinión. En primer lugar, las interpretaciones literales no son las más adecuadas para las disposiciones constitucionales; es más importante atender a la garantía que pueden establecer para las personas y a la justa atribución de potestades a los órganos del poder público. En segundo lugar, los títulos ejecutivos no creados por pronunciamiento judicial en materias diferentes al Derecho administrativo no pueden ser tratados como los títulos ejecutivos que establecen un deber de prestación regido por el Derecho público y en favor de las Administraciones públicas, sencillamente porque en el caso de títulos extrajudiciales privados no existe nada de eso y, por tanto, tampoco base para una potestad pública de autotutela ejecutiva. O bien se abre el camino a una estricta autotutela ejecutiva privada ${ }^{21}$, o bien hay que atribuirle la potestad a un tercero sobre ejecutante y ejecutado -no como la Administración, que actúa como ejecutante frente al ejecutado- cuya función de juzgar, en estos supuestos, consiste en comprobar si hay o no un título ejecutivo y en qué medida debe dársele eficacia. Y ese tercero sólo puede ser un juez.

El segundo problema es en qué consiste la potestad de ejecución, como parte de la potestad jurisdiccional exclusivamente atribuible a los órganos jurisdiccionales. En este aspecto, el art. 117.3 CE se expresa de un modo que, sin perjuicio de las garantías que veremos, deja al legislador ordinario un ámbito de configuración normativa bastante amplio. En efecto, la disposición no dice que la potestad jurisdiccional consista en ejecutar lo juzgado, sino en hacerlo ejecutar.

De esa matizada expresión del precepto constitucional se deducen dos consecuencias.

La primera es que facilita entender que tan legítima desde el punto de vista constitucional es una ejecución por medios de subrogación -en la que, si la na-

${ }^{21}$ Eso es lo que hace el art. 129 LH cuando dispone que: "Además, en la escritura de constitución de la hipoteca podrá pactarse la venta extrajudicial del bien hipotecado, conforme al artículo 1858 del Código Civil , para el caso de falta de cumplimiento de la obligación garantizada. La venta extrajudicial se realizará por medio de notario, con las formalidades establecidas en el Reglamento Hipotecario". La nueva redacción del precepto deja claro que no estamos ante un proceso de ejecución y elimina las dudas de inconstitucionalidad que, a veces, manifestó la jurisprudencia de la Sala de lo Civil del TS; brevemente sobre esto, véase Martín PASTOR, J., con otros autores, Derecho Procesal Civil, Cizur Menor (Navarra), 2010, Aranzadi Thomson Reuters, pp.844-845. En la misma obra, p. 689, ya expresé que la tesis de la inconstitucionalidad era probablemente "errónea puesto que el notario -cuya intervención es necesaria en calidad de fedatario público, como en otros supuestos similares de obtención del valor de bienes del deudor sin actuación judicial (arts. 1872 CC, 16.2 Ley de Venta a Plazos de Bienes Muebles de 13 de julio de 1998)- no ejerce ninguna potestad de ejecución, ninguna coerción ni jurídica ni material sobre el patrimonio del deudor. La coerción que supondría el embargo es suplida por la voluntaria constitución de la hipoteca. La que significaría la adjudicación al mejor postor en la subasta se evita también porque, al constituirse la hipoteca, ha sido designada una persona para que, de ser necesario, otorgue la escritura en nombre del hipotecante". 
turaleza del deber de prestación lo permite, el órgano jurisdiccional sustituye la acción del ejecutado sobre su patrimonio para satisfacer el derecho del ejecutante-, como una ejecución por medios de coacción -en la que el órgano jurisdiccional tiene instrumentos para presionar legítima y efectivamente al ejecutado para que realice la prestación ${ }^{22}$. Quisiera insistir en que la anterior afirmación se hace desde la perspectiva de la constitucionalidad, no desde el punto de vista de la mayor efectividad y eficiencia del proceso de ejecución. La valoraciones de efectividad y eficiencia tienen respuestas muy diversificadas en función de factores igualmente diversos; la doctrina puede sostener -preferible que con suficiente fundamentodiferentes tesis sobre las mismas, pero el legislador puede optar entre opciones político-jurídicas igualmente legítimas desde el punto de vista constitucional.

La segunda consecuencia -que puede tener algún contacto con la anterior- está más implicada en el tema que tratamos en este artículo. La expresión constitucional da cobertura a un régimen legal de la ejecución en el que no sea el juez quien deba realizar directamente los actos ejecutivos, aunque, en todo caso, sí que deberá tener atribuida la potestad de ordenar que esos actos se realicen y disponer de instrumentos para hacer efectiva esa orden suya.

No creo que sea razonable restringir, con argumentos radicales de inconstitucionalidad, las opciones de atribución de poderes y funciones en el proceso de ejecución que el art. 117.3 CE -con su matizada expresión- deja abiertas ante el legislador ordinario.

En primer lugar, ni siquiera cuando se entendía que el juez tenía atribuidas las más amplias potestades para el desarrollo del proceso de ejecución, era el juez quien debía realizar directamente todos los actos de poder público necesarios para completar ese proceso. En los embargos domiciliarios (diligencias de embargo en el domicilio o locales del ejecutado) y en los desahucios se reconocía que el agente judicial actuaba con autoridad delegada del juez. ${ }^{23}$ Aunque podría entenderse que eso era precisamente significativo de la omnipresencia del juez -aquí mediante un delegado-, la realidad era que la actuación procesal del órgano jurisdiccional se producía, en estos casos, mediante la acción de personal auxiliar, que, claramente en el caso del embargo, actuaba con base en una orden genérica del juez de que fueran embargados bienes suficientes del ejecutado, que el agente judicial (o el auxiliar judicial) concretaba con plena eficacia jurídica al determinar el bien que debía ser incluido en la diligencia (art. 587.1 LEC) y que estaba sujeto a los controles judiciales, de oficio (art. 609), o a instancia de parte (art. 532.1.3 y 2 LEC) previstos por la ley.

22 Sobre los instrumentos ejecutivos en general, puede verse Ortells Ramos, Derecho Procesal Civil, cit., pp. 702-704.

23 Prieto-Castro, L., Derecho de los Tribunales, Aranzadi, Pamplona, 1986, pp. 367-368. 
En segundo lugar, en los procesos de ejecución penal -en cuanto a la ejecución de penas privativas de libertad- y contencioso-administrativo, en cada uno de ellos por razones diferentes, el juez aparece situado en una posición que representa más claramente la estructura de poderes característica del "hacer ejecutar", que la de ejecutar directamente. Sin embargo, eso no significa que el juez no tenga atribuida la máxima potestad sobre el desarrollo de la ejecución, sino que, para el ejercicio de la misma, se sirve de las funciones de auxiliares y de colaboradores ${ }^{24}$.

Centrando la atención en el proceso civil de ejecución, y sin descender a detalles, la ley № 13/2009 ha concretado el "hacer ejecutar lo juzgado" con una regulación en la que el juez domina la ejecución en un doble aspecto:

$1^{\circ}$ ) Tiene la potestad de ordenar que se realice la ejecución, tras el examen del título ejecutivo, determinando su alcance subjetivo (arts. 551.1, 540 al 544, 704.2 LEC) y objetivo (arts. 551.1, 572.2, 575, 576 a 578 LEC). La potestad de determinar el alcance objetivo comprende la de apreciar que debe ser modificada la prestación ejecutable en los supuestos previstos por la ley y la de determinar la entidad de la prestación sustitutiva (arts. 701.3, 702.2, 706.2, pár. segundo, 709.2, pár. segundo, 712 y siguientes LEC). También tiene la potestad de decidir que no continúe la ejecución que hubiera ordenado iniciar (arts. $559,561,566,567$ y 569 LEC).

$2^{\circ}$ ) Tiene potestades de control sobre el ejercicio de las potestades para la ejecución ${ }^{25}$ que la ley atribuye al secretario judicial. El control se ejerce, en unos supuestos, de oficio (arts. 225.6 $6^{\circ}, 562.2$ y 609 LEC); en otros, a instancia de parte, mediante el mal Ilamado "recurso de revisión" (arts. 531, 551.5 -norma de gran fuerza expansiva, porque es aplicable a toda resolución del secretario sobre el cumplimiento del despacho de ejecución-, 558.2 y 570 LEC).

Al secretario judicial se le atribuyen las potestades de aplicar los instrumentos ejecutivos que la ley ha establecido para la ejecución judicialmente despachada, en función de las características relevantes de ésta (así, en general, el art. 551.3 LEC). Pero esta regla general experimenta restricciones que mantienen en

\footnotetext{
24 Para mayor detalle sobre cómo se garantiza el "dominio" por el juez de la ejecución de las penas privativas de libertad, PeiteAdo Mariscal, P., La ejecución jurisdiccional de condenas privativas de libertad, Edersa, Madrid, 2000, passim. Para lo mismo, respecto de la ejecución en el proceso contenciosoadministrativo, después de que la LJCA de 1998 corrigiera ciertas ambigüedades de la ley anterior, Comentarios a la Ley de la Jurisdicción Contencioso-Administrativa de 1998, Civitas, Madrid, 1999, pp. 715-800.

25 Esta potestad de control efectivo por parte de los tribunales era la que exigía el TC para entender conforme a CE la regulación de la ejecución en la LJCA de 1956: véanse, entre otras, las STC 32/1982, de 7 de junio; STC 67/1984, de 7 de junio; STC 109/1984, de 26 de noviembre; STC 155/1985, de 12 de noviembre.
} 
manos del juez potestades que, en principio, podrían entenderse comprendidas en aquélla. Así, el secretario judicial no puede: ${ }^{26}$

$\left.1^{\circ}\right)$ Imponer multas coercitivas a quien no tenga la condición de ejecutado (art. 591.2 LEC), aunque estas multas sean uno de los instrumentos legales para hacer cumplir el deber de colaboración de los terceros en la ejecución.

$2^{\circ}$ ) Resolver sobre la pertenencia de los bienes al ejecutado a efectos de su embargo, si un tercero ha impugnado preventivamente tal pertenencia (art. 593.2 LEC). Y ello aunque el secretario judicial sí que ha podido apreciar los indicios de pertenencia para decidir inicialmente la afección.

$3^{\circ}$ ) Determinar el régimen de la administración judicial si no hay acuerdo entre las partes (art. 631.1, pár. tercero LEC), aunque la administración es una garantía de la afección que él ha podido decretar.

$5^{\circ}$ ) Aplicar los medios ejecutivos previstos en caso de condena a emitir una declaración de voluntad (art. 708 LEC).

$6^{\circ}$ ) Apreciar si la prestación de hacer impuesta por el título ejecutivo tiene carácter de hacer personalísimo (art. 709 LEC).

Esta atribución de potestades me parece constitucionalmente impecable, con un única duda debida a la falta de previsión del "recurso de revisión" con una norma general que impida que ninguna resolución del secretario judicial quede exenta de control por el juez. La falta de esa previsión es evidente con sólo observar el art. 562 LEC. Pero la consecuencia de que pueda haber resoluciones del secretario judicial exentas de control por el juez queda excluida por lo dispuesto en el art. 454bis.1 LEC, que, en casos de falta de previsión legal de ese recurso, permite someter la cuestión al juez en la primera oportunidad de actuación ante él y, en todo caso, antes de que se dicte resolución definitiva ${ }^{27}$.

\section{C) Las potestades de dirección y tramitación del proceso}

Las potestades de juzgar y de hacer ejecutar lo juzgado no pueden ser ejercitadas instantáneamente, apenas haya sido formulada la demanda u otra solicitud inicial de los procedimientos en los que se ejercitan aquellas potestades.

El ejercicio acertado y justo de esas potestades requiere, no sólo por la naturaleza de las cosas, sino también por imperativo constitucional, del proceso como actividad jurídica dirigida por el órgano jurisdiccional, e integrada

\footnotetext{
${ }^{26}$ No menciono ahora la dudosa competencia del secretario judicial en casos de mejora, reducción o modificación del embargo, porque el art. 612 LEC es una clara muestra de deficiente técnica legislativa, que después consideraremos.

27 En el proceso de ejecución sería antes de que se dicte el decreto del secretario que le pone término, o, incluso, aprovechando el "recurso de revisión" que, en este caso, la LEC prevé expresamente en el art. 570 .
} 
por actos de aportación y de recepción de materiales procesales (peticiones, alegaciones, pruebas), y, dado que lo anterior se realiza de acuerdo con una ordenación legal, por actos que vayan dando cumplimiento concreto a esa ordenación, dirigiendo e impulsando el desarrollo del procedimiento (decisiones de admisión e inadmisión de actos de parte, decisiones de que se proceda de determinada manera ante ciertos hechos o actos) y realizando ese desarrollo (mediante actos de recepción de material procesal, de comunicación de diversas clases, de petición de auxilio judicial y a la Justicia, etc.) hasta su término.

El art. 117. 3 CE no permite que la potestad jurisdiccional de juzgar y hacer ejecutar lo juzgado pueda ser ejercitada de cualquier modo, sino que somete su ejercicio a las normas de procedimiento que las leyes establezcan. E incluso la regulación legal del procedimiento judicial no es indiferente al legislador constitucional, que establece normas tanto respecto de la forma del mismo (art. $120 \mathrm{CE}$ ), como respecto de los derechos de las partes (art. 24.1 y $2 \mathrm{CE}$ ) y de los poderes del juez (art. $118 \mathrm{CE}$ ). En consecuencia, no sería correcto sostener que, por proyectarse sobre una relación de la que el propio órgano jurisdiccional es sujeto, las potestades de éste referidas a la relación jurídica procesal no son jurisdiccionales, o son, de algún modo, "menos" jurisdiccionales. El ordenamiento constitucional impide que esas potestades le sean sustraídas al órgano jurisdiccional.

Probablemente lo que se acaba de afirmar es tan obvio, que el TC no ha tenido muchas oportunidades de expresarlo en su doctrina. Por eso tienen especial interés las STC 187/1988, de 17 de octubre y STC 18/1991, de 31 de enero, ambas relativas a recursos de inconstitucionalidad contra leyes autonómicas que invadían, en favor de los órganos autonómicos de control presupuestario externo, las potestades de instrucción del Tribunal de Cuentas en el ejercicio de su potestad jurisdiccional en materia de enjuiciamiento contable. Frente a la tesis de que esta potestad no resultaba afectada por la regulación por ley autonómica de una parte de la actividad instructoria que serviría para que el Tribunal de Cuentas resolviera en definitiva sobre la responsabilidad contable, el TC sostiene que las actividades de "instrucción de procedimientos jurisdiccionales aparecen estrechamente vinculadas al enjuiciamiento estricto por responsabilidades contables", así como que están "directamente orientadas al enjuiciamiento y en su caso, exigencia de responsabilidad y, por tanto, incluidas en el procedimiento enjuiciador y reservadas al Tribunal de Cuentas".

Dicho lo anterior, se debe también sostener que el legislador ordinario dispone de un ámbito de libre configuración normativa para regular específicamente las potestades de dirección del proceso en sentido amplio. Ese ámbito abarca desde modelos con una intervención muy directa y continuada del titular del órgano jurisdiccional, hasta modelos en los que es muy importante el apoyo y colaboración que presta a la actividad de dirección el personal auxiliar no jurisdiccional. 
De nuevo las dos STC mencionadas tienen interés para justificar lo que se acaba de decir. En los casos de esas sentencias el TC tuvo presente, sin reproche de inconstitucionalidad, una previsión legal del art. 26.3 LO 2/1982, del Tribunal de Cuentas que autoriza a este Tribunal a delegar ${ }^{28}$ en órganos autonómicos de control externo del gasto público -que no son órganos jurisdiccionales, ni dependen orgánicamente del Tribunal de Cuentas- la actividad instructora del procedimiento de enjuiciamiento contable.

La apreciación de la constitucionalidad de la regulación establecida por el legislador sobre esta materia no dependerá sólo, ni principalmente, de lo que dispone el art. 117.3 CE -la indisoluble vinculación entre ejercicio de potestad jurisdiccional y proceso-, sino de las normas constitucionales que se proyectan sobre diversos componentes básicos del proceso. Por ejemplo: el derecho a que sea un juez quien se pronuncie sobre la inadmisión de una petición de tutela judicial y sobre la concurrencia de circunstancias que impidan el pronunciamiento sobre el fondo de la misma -en cuanto esa decisión afecta al contenido esencial del derecho a la tutela judicial efectiva-, la prohibición de indefensión -que impone que las partes puedan hacer llegar al juez los elementos relevantes para la resolución que debe dictar; previamente, que puedan tener conocimiento de los mismos; y que sea un juez quien resuelva sobre la admisión de las aportaciones-, el derecho a la prueba -sobre cuyo alcance concreto, en cuanto a proposición y práctica, debe decidir un juez-, el derecho a la igualdad en el proceso, el derecho a un proceso sin dilaciones indebidas, y -aunque estimo difícil una valoración de inconstitucionalidad sólo por esta razón-29 la norma de que el procedimiento debe ser "predominantemente oral".

En definitiva, no comparto las razones que se arguyen en la "Declaración de profesionales jurídicos" para justificar la constitucionalidad de las normas sobre atribución de potestades sobre dirección del proceso al secretario judicial. Ahora bien, eso no quiere decir que piense que en la regulación de la ley No 13/2009 hay normas sobre esa materia que susciten dudas de constitucionalidad.

\section{Sobre La EFECTIVIDAD Y efICIENCIA DE LAS ATRIBUCIONES DE POTESTADES A JUEZ Y A SECRETARIO JUDICIAL POR LA LEY N $\mathrm{N}^{\circ} 13 / 2009$}

Otra valoración de la reforma consiste en examinar si contribuye a que el proceso mejore en cuanto a su efectividad y su eficiencia, tanto en su desarrollo, como en sus resultados finales. La efectividad en el desarrollo tiene que ver con

\footnotetext{
${ }^{28}$ Por cierto, algo muy distinto a lo que disponían las leyes impugnadas, que atribuían las competencias instructorias por su propio imperio a los órganos autonómicos de control externo del gasto público y no las hacían depender de la delegación del Tribunal de Cuentas.

29 Pienso que lo que será decisivo es que el régimen legal de los actos genere indefensión.
} 
la reducción de actividades procesales fallidas y, en definitiva, con la evitación de dilaciones indebidas. La efectividad de los resultados guarda relación con el acierto de las sentencias y con la satisfacción de los ejecutantes en el proceso de ejecución. La eficiencia aprecia la proporción entre los medios aplicados y los resultados obtenidos y su calidad.

La efectividad y la eficiencia del proceso no dependen sólo, ni siquiera en primer lugar, de una determinada atribución de potestades al personal encargado de apoyar el ejercicio de la potestad jurisdiccional. Son más importantes una adecuada organización judicial y su ajuste a las condiciones territoriales y socioeconómicas del Estado en el que se implanta y una ordenación de los procesos orientada a aquellos objetivos ${ }^{30}$. Por lo demás, esos factores están interrelacionados y los que son más decisivos deben condicionar la conformación de otras componentes para que no sólo no sean disfuncionales respecto de opciones de mayor rango, sino que contribuyan a sus buenos resultados.

La reforma que mencionamos es uno de esos componentes que acabamos de mencionar. Pero, aunque aquí vamos a prestar más atención a las potestades que atribuye al secretario judicial, en realidad eso forma parte de un conjunto más amplio, que es el de la organización del trabajo de los empleados públicos que prestan apoyo al ejercicio de la potestad jurisdiccional.

El cambio que se introduce en esa organización puede sintetizarse en la expresión "nueva oficina judicial". Manifiesta una toma de conciencia -tardía en cuanto al carácter general de la modificación necesaria- ${ }^{31}$ de las transformaciones producidas tanto en la litigiosidad, como en la dotación de medios personales y materiales a la Administración de justicia. Cuando estos medios han alcanzado un notable nivel -en número de efectivos y cualificación técnica de los mismos-, imprescindible para atender una demanda de justicia cada vez más elevada, se ha asumido que no era razonable continuar prescindiendo de las técnicas de organización del trabajo que se aplican en empresas y Administraciones públicas para optimizar los medios disponibles.

Es cierto que, en este caso, esas técnicas deben ser aplicadas teniendo en cuenta que se hallan al servicio del Poder judicial, cuyos titulares -jueces y

\footnotetext{
30 Para una aproximación a las relaciones entre oralidad y escritura de los procesos y la eficiencia de los mismos, véanse los trabajos recogidos en Carpi, F., Ortells, M. (Ed.), Oralidad y escritura en un proceso civil eficiente/Oral and written proceedings: efficiency in civil procedure, 2 vols., Servei de Publicacions de la Universitat de València, Valencia, 2008; también Ortells Ramos, M., "Formas del procedimiento y garantías fundamentales del proceso civil", en lus et Praxis, año 16, № 1, 2010, pp. 395-440.

31 Con anterioridad ha habido actuaciones parciales, a veces de ámbito limitado, como los intentos de racionalización del trabajo a través del funcionamiento, más o menos formalizado, de servicios comunes, la "externalización" y la uniformidad en el funcionamiento del servicio de depósitos y consignaciones judiciales.
} 
magistrados- tienen reconocida y garantizada la independencia personal y están investidos de una potestad suprema, en cuanto expresión funcional de uno de los Poderes del Estado.

Pero, cuando la propia Constitución reconoce como derecho fundamental que las personas tienen derecho a obtener de los jueces y magistrados una tutela que ha de ser efectiva (art. 24.1 CE), han de recibirla en un proceso sin dilaciones indebidas (art. 24.2 CE), y también dispone que el Estado contraerá responsabilidad por el funcionamiento anormal de la Administración de justicia (art. $121 \mathrm{CE}$ ), es inexcusable la aplicación de técnicas de organización racional del trabajo, con las adecuaciones requeridas por la potestad jurisdiccional, a cuyo ejercicio habrán de servir.

\section{Sobre los aspectos generales de las opciones organizativas}

La mejora de los medios personales ${ }^{32}$ y materiales ${ }^{33}$ al servicio de la Administración de justicia requiere, para su adecuada gestión, estructuras organizativas que ni han de estar integradas, ni dirigidas, por técnicos jurídicos ${ }^{34}$. No es en este ámbito donde se plantean los mayores problemas.

La actividad más abundante, específica y con significación jurídica que se desarrolla en los juzgados y tribunales es la actividad procesal que, además, es inseparable del ejercicio de la potestad jurisdiccional. Los problemas surgen, precisamente, respecto de las diferentes opciones para organizar más racionalmente la realización de esa actividad.

Es útil, antes de referirse a los problemas que afectan a la elección entre las grandes opciones organizativas, hacer una catálogo, tal vez superficial, de aquellas partes de la actividad procesal que, en mayor medida, permiten una racionalización y, al mismo tiempo, la requieren más intensamente y responden a la misma con buenos resultados:

$\left.1^{\circ}\right)$ Hay actos del tribunal que deben realizarse fuera de su edificio-sede, con desplazamiento del personal auxiliar (actos de comunicación domiciliaria, embargos domiciliarios, desalojos, etc.). La eficiencia puede mejorar si se programa la realización de varios de esos actos por zonas. Esta técnica no impide atender necesidades de actuación urgente, que pueden ser programadas específicamente o exceptuadas de programación.

\footnotetext{
32 Incorporación como auxiliares de profesionales en técnicas no jurídicas.

${ }^{33}$ Edificios cuyo mantenimiento requiere diferentes tipos de asistencias técnicas, medios informáticos y audiovisuales que también necesitan ese tipo de asistencia.

34 Sobre las Ilamadas unidades administrativas y las oficinas comunes de apoyo, véase, p. ej., ORTELLS Ramos, M., "La Administración de justicia", en Baño León, J. M. (coord.), Comentario al Estatuto de Autonomía de la Comunidad Valenciana, Thomson Civitas, Madrid, 2007, pp. 371-372.
} 
$\left.2^{\circ}\right)$ Muchos actos escritos de tramitación del proceso en el ámbito del juzgado o tribunal tienen contenidos en gran medida iguales, cualquiera sea el objeto y las partes del proceso en el que se realizan. El perfeccionamiento de esos contenidos y la generalización de su uso, facilitan, por un lado, la realización de un parte de la actividad procesal, y, por otra parte, contribuye a extender las mejoras en su calidad.

$3^{\circ}$ ) Las leyes procesales, específicamente aquellas de sus disposiciones que regulan procedimiento, son precisamente leyes que pautan el desarrollo de actividad. No obstante, el nivel de detalle de esa pauta no es suficiente para ordenar la actividad de las diversas clases de empleados públicos que, dentro de la estructura orgánica de juzgados y tribunales, dan soporte al ejercicio de la potestad jurisdiccional. Las técnicas de las relaciones de puestos de trabajo -con especificación de sus funciones-y de las instrucciones generales, permiten completar una necesaria ordenación detallada de la actividad en el ámbito interno del tribunal.

$4^{\circ}$ ) La utilización de la informática no sólo como medio auxiliar de la actividad procesal, sino como medio para la realización de esa actividad, en sustitución de la parte de la misma que actualmente se realiza mediante escritura sobre papel ${ }^{35}$, incrementa la necesidad de uniformar la actividad procesal en los aspectos a los que nos hemos referido en los dos números anteriores. La utilización de la técnica informática impone una precisa protocolización y estandarización de las actividades. Eso tiene inconvenientes que después apuntaremos, pero, en general, contribuye a un desarrollo más ágil y eficiente de la actividad procesal.

$5^{\circ}$ ) La celebración de vistas y de juicios orales requiere el uso de espacios físicos idóneos, dotados de medios técnicos que posibiliten la realización de aquellas actuaciones procesales con todos los requisitos que establece la ley. El criterio de eficiencia requiere programar la ocupación de estos espacios para optimizar su uso, tanto más cuanto si esos espacios están adecuadamente dotados, los costes de su establecimiento y mantenimiento son elevados.

El problema organizativo más general, si se consideran las actividades brevemente reseñadas, es el de a quién se debe atribuir la potestad de dirección sobre esas actividades y su concreta realización, para mejor garantizar la consecución de los objetivos de efectividad y eficiencia. La solución ha sido atribuir la dirección al secretario judicial y la concreta realización a la oficina

\footnotetext{
35 Puede verse, entre muchos, Ortells Ramos, M., "Incidencia de las nuevas tecnologías en el proceso jurisdiccional. Especial análisis de las cuestiones referentes a la prueba, a las medidas cautelares y a las comunicaciones procesales", en XVIII Jornadas Iberoamericanas y XI Uruguayas de Derecho Procesal. En homenaje a la Escuela procesalista Uruguaya, Fundación de Cultura Universitaria, Montevideo, 2002, pp. 607-675.
} 
judicial, salvo excepciones en que potestades de dirección y tramitación del proceso se atribuyen al juez.

En apretado resumen: ${ }^{36}$

$1^{\circ}$ ) Salvo en los supuestos en que los actos de las partes se deben producir directamente ante el juez (arts. 229 LOPJ, 137 LEC), deben ser presentados en la oficina judicial que presta servicio al órgano jurisdiccional competente. La oficina los recibe, constata su presentación (qué acto se ha presentado, por quién y cuándo) y los transmite a quien puede resolver sobre la eficacia procesal del acto presentado (el secretario judicial o el juez según características del acto).

$\left.2^{\circ}\right)$ Los actos recibidos por el órgano jurisdiccional, el hecho (negativo) de la falta de presentación de esos actos, los actos del titular del órgano jurisdiccional y los hechos jurídicos que afectan a un proceso, han de ser jurídicamente valorados para determinar sus consecuencias jurídicas sobre el desarrollo del procedimiento con arreglo a la ley. Se trata de la tramitación: de decidir cuál debe ser y de realizarla. En unos casos, esa determinación de consecuencias consiste en que el personal de la oficina judicial lleve a cabo un comportamiento establecido por la ley. Ése es el caso de las que el art. 456.2 LOPJ denomina diligencias de comunicación y diligencias de ejecución. Las primeras consisten en un comportamiento específico: poner algo en conocimiento de alguien (de partes, de terceros). Las diligencias de ejecución ${ }^{37}$ tienen un contenido más genérico: cualquier otra conducta para el desarrollo del procedimiento, diferente a la de realizar comunicaciones.

$3^{\circ}$ ) En otros casos, la determinación de las consecuencias que los actos y los hechos jurídicos deben tener en el desarrollo del procedimiento consiste en emitir una orden de que se haga algo, en adoptar una resolución sobre el desarrollo del procedimiento. Ése es el caso de las diligencias de ordenación, que son resoluciones sobre la tramitación del procedimiento para cuya emisión la ley atribuye potestad al secretario judicial, sin perjuicio de las potestades de control que corresponden al titular del órgano jurisdiccional. Los objetos legales de estas resoluciones son el avance del procedimiento y el modo en que debe avanzar, aplicando concretamente los preceptos de la ley procesal en atención a los actos realizados y a los hechos ocurridos en el proceso (así, con otras palabras, arts. 456.1 y 2 LOPJ, 144 bis LECrim, 206.4.1 ${ }^{\text {a } 206.2 .1^{a}}$

\footnotetext{
36 Para un desarrollo más amplio puede verse Ortells Ramos et al., Introducción al Derecho Procesal, cit., pp. 414-429.

37 No deben ser confundidas con los actos del secretario judicial en un proceso de ejecución, porque los más importantes de esos actos no son diligencias, sino resoluciones en forma de decreto (arts. $568.2,583.3,587.1$ y 589.3 LEC).
} 
LEC), con excepción de las decisiones de tramitación "que las leyes procesales reserven a jueces y magistrados" (art. 456.2 LOPJ) ${ }^{38}$.

La solución me parece acertada en términos generales. Concurren razones favorables a la atribución al secretario judicial, con razones desfavorables a la atribución a los jueces -que hubiera sido la alternativa-.

De entrada, la formación jurídica previa al acceso al Cuerpo de secretarios judiciales y el procedimiento de selección de los mismos garantizan una buena cualificación jurídica de los secretario judicial.

En segundo lugar, la atribución a los jueces -a cada uno de ellos o especialmente a algunos de ellos- lo hubiera sido en detrimento de aplicar la capacidad de trabajo de los mismos al ejercicio de potestades que, en ninguna medida, son atribuibles a quienes carezcan de la condición de juez (determinados actos de dirección procesal, recepción de alegaciones y pruebas, emisión de sentencias y de resoluciones sobre la tutela cautelar y la tutela ejecutiva). La atribución al secretario judicial no merma su capacidad de trabajo; las tareas encargadas corresponden al ámbito tradicional de su actividad y, al haberse clarificado las atribuciones, pueden esperarse mejoras en la efectividad y eficiencia con las que esa actividad se desarrolla.

La anterior consideración tiene que ver con el diferente estatuto como empleados públicos del juez y del secretario judicial. Precisamente esta diferencia de estatutos conduce a otras razones favorables a la atribución a los secretarios judiciales, y que desaconsejan la atribución a jueces.

La racionalización de las actividades procesales a las que me he referido poco antes genera sus mejores resultados en estructuras organizativas de determinado tamaño -que permitan aplicar economías de escala- y con el establecimiento de líneas jerárquicas de dirección destinadas a conseguir una uniformidad de funcionamiento de esas estructuras.

El estatuto del secretario judicial posibilita su inserción en estructuras organizativas en las que rige el principio jerárquico ${ }^{39}$. Por el contrario, la CE (art. 117.1) no permite que los jueces sean sometidos a dependencia jerárquica en

\footnotetext{
${ }^{38}$ La delimitación de atribuciones sobre las resoluciones de tramitación se hace por el legislador con un alcance matizado. Así, por ejemplo: $1^{\circ}$ ) El secretario judicial puede dictar resoluciones de admisión de actos y de no admisión provisional de los mismos por defectos subsanables, pero no puede resolver la inadmisión de actos, ni siquiera por falta de subsanación de los defectos advertidos por él mismo (arts. 81, 193 LPL, 45.3, 56.2, 85.2 LJCA, 404.1, 457 LEC). $2^{\circ}$ ) El secretario judicial puede dictar diligencias de ordenación señalando día y hora de celebración de vistas y comparecencias ante el órgano jurisdiccional, pero con sujeción a criterios previos -algunos fijados por el titular unipersonal del órgano jurisdiccional o su presidente- cuya aplicación es controlada por éstos antes de que se practique el acto de citación (art.182 LEC).

39 Arts. 452.1, 463.1, 465.8 LOPJ, que, por otra parte, dejan a salvo la independencia del secretario judicial en el ejercicio de la fe pública.
} 
el ejercicio de la potestad jurisdiccional. Si los poderes que consideramos se hubieran atribuido a jueces, el problema hubiera sido cómo justificar la subordinación de otros jueces, aunque fuera respecto del ejercicio de alguno de sus poderes de dirección procesal.

2. La "última palabra" de los jueces sobre la dirección procesal del secretario judicial y la reducción de su "incidencia negativa" sobre los objetivos de efectividad y eficiencia

La opción organizativa general que ha quedado expuesta comprende, como se ha anticipado, supuestos en los que el juez tiene directamente la potestad de dirección procesal, y también diversos instrumentos mediante los cuales el juez ejerce una potestad de control de resoluciones previas del secretario judicial y de actos de tramitación de la oficina judicial que éste dirige.

El juez ejerce estas potestades con independencia y con exclusiva sumisión a la ley. Obviamente sin vinculación a las órdenes e instrucciones de servicio relativas a la actividad del secretario judicial y de la oficina judicial (art. 465.8 LOPJ). La resolución del juez sobre una cuestión procesal singular alterará la uniformidad en el desarrollo de la actividad procesal y, por ello, puede considerarse un inconveniente o factor negativo desde el punto de vista de los objetivos de efectividad y eficiencia.

El carácter prioritario de la independencia del juez a la hora de aplicar la ley (en este caso, la ley procesal), excluye, en mi opinión, que esas valoraciones negativas sean correctas. La resolución del juez ni siquiera será significativa de una dilación indebida, en la medida en que el juez considere que la ley imponía decidir como él lo hace cuando ha tenido oportunidad de examinar la correspondiente cuestión procesal.

Lo que se acaba de decir no impide, sin embargo, reconocer que:

$1^{\circ}$ ) Si la rectificación por el juez de la actividad de dirección y tramitación procesal del secretario judicial y de la oficina judicial se produce con frecuencia, pierde utilidad la opción legal general de encomendar al secretario judicial un amplio sector de la actividad procesal.

$2^{\circ}$ ) Es un objetivo razonable el de reducir-siempre de manera respetuosa con la independencia judicial- las probabilidades de que el juez entienda que debe revocar resoluciones de dirección del secretario judicial o determinar que están viciados por alguna clase de ineficacia actos de tramitación, adoptadas y realizados, respectivamente, de acuerdo con las instrucciones para la uniformidad de parte de la actividad procesal.

Cumpliría los requisitos apuntados una técnica que posibilitara que las juntas de jueces (art. 170 LOPJ) y las juntas de magistrados de diversas secciones de una misma sala (art. 264 LOPJ), competentes para tratar de la unificación de 
criterios y de prácticas, pudieran aportar sus observaciones en el procedimiento de elaboración de circulares e instrucciones de servicio (arts. 456.8, 467.1 LOPJ). Esta técnica tendría la dificultad de que, según la autoridad competente para dictar las órdenes e instrucciones, deberían ser muchas las juntas Ilamadas a informar ${ }^{40}$.

Es cierto que, aunque fuera superada esa dificultad, y en los textos finales fueran aceptadas todas las observaciones de las juntas, los jueces y magistrados no quedarían vinculados. Pero eso ya es así con los acuerdos de las propias juntas (art. 267.2 LOPJ). No obstante, la implicación en la elaboración del texto siempre favorecería una mayor aceptación del mismo y una tendencia a reducir las resoluciones singulares divergentes de los criterios generales.

En cualquier caso, y respecto de la específica uniformación de la actividad procesal determinada por la informatización de la tramitación, es imprescindible que las posibilidades de tramitación procesal permitidas por las aplicaciones informáticas se ajusten plenamente a las posibilidades legales de tramitación, en vez de reducir éstas o someterlas a requisitos diferentes a los legales ${ }^{41}$.

Otra faceta de la incidencia del control judicial de un previo acto de dirección del secretario judicial sobre la eficiencia de la opción organizativa que ha hecho el legislador, es la derivada del excesivo retraso en la entrada en juego de aquel control.

Pongo dos ejemplos de regulación conducente a ineficiencias:

$\left.1^{\circ}\right)$ El secretario judicial puede admitir el acto de preparación del recurso de apelación (art. 457.3 LEC), sin que la diligencia de ordenación sea inmediatamente impugnable ante el juez a quo; la parte recurrida podrá hacer valer las causas de no admisión al oponerse a la interposición del recurso (arts. 457.5 y 461 LEC). Si el tribunal a quo o el ad quem no establecen interpretaciones que posibiliten el control judicial en otro momento, un eventual pronunciamiento de inadmisión tendrá que esperar a la resolución final de la apelación. La parte apelada se habrá visto forzada a desarrollar inútilmente toda su actividad defensiva en la apelación, que, con la misma inutilidad, habrá ocupado a los tribunales.

Esta ineficiencia también existe en los trámites de los recursos extraordinarios (arts. 470.2 y 480.1 LEC), aunque el alcance de las consecuencias negativas es

\footnotetext{
40 El concurso del punto de vista de los jueces es un tema que preocupa, y se proponen soluciones distintas a la tal vez poco practicable que apunto en el texto: Dolado Pérez, A., "Hacia una administración de justicia asimétrica", en Práctica de Tribunales, № 83, junio de 2011, pp. 56-57.

41 Sobre la realidad del problema, Dolado Pérez, "Hacia una administración de justicia asimétrica", cit., p.58. Este problema, nada infrecuente, sería la versión menos sofisticada de la "regulación por medio del código", en terminología de LessiG, L., El código y otras leyes del ciberespacio, Taurus Digital, Madrid, 2001, pp. 51-52.
} 
menor, porque las causas de inadmisión son alegables al comparecer ante el tribunal ad quem, que tiene una clara e inmediata posibilidad legal de resolver la inadmisión.

$2^{\circ}$ ) El art. 454 bis.1, pár. primero LEC, establece una norma que habilita el control judicial de resoluciones de dirección procesal del secretario judicial, incluso cuando no procediera el control de oficio por exceso de poder del secretario judicial, o la resolución no fuera legalmente atacable mediante la impugnación mal llamada recurso de revisión. Sin embargo, ese control judicial, cuya posibilidad generaliza aquella disposición, puede ser demasiado tardío $y$, por tanto, generar ineficiencias por permitir el excesivo desarrollo de una actividad procesal que, a la postre, podrá ser anulada.

\section{La buena téCniCa leGislativa: un instrumento "BARATO" PARA MEjORAR la EFICIENCIA DE LA ACTIVIDAD PROCESAL}

La reforma de la que estamos tratando será, si se hace bien, una reforma cara. Dejando aparte el previsible incremento de los costes de personal, que frecuentemente acompaña a las reorganizaciones que afectan a éste, hay que contar con un proceso de informatización complejo por muchas razones, entre ellas los muy diversos "puntos" que deberán quedar interconectados, y la adecuación del parque de edificios que acogen las instalaciones judiciales.

Es tal la importancia, en términos económicos, de los elementos mencionados-importancia que se acrecienta en coyunturas en las que el gasto público debe contenerse- que puede hacer olvidar que hay un factor muy influyente en el éxito de la reforma, porque favorece que el desarrollo de la actividad procesal se ajuste a las previsiones legales, con el menor número posible de inseguridades, que son fuente de frecuentes incidencias e impugnaciones. Este factor, además tiene un coste incomparablemente menor al de los otros elementos que también son indispensables. Me refiero a la importancia de una ley bien hecha.

Pues bien, en cuanto a técnica legislativa, las leyes que, hasta ahora, han configurado esta reforma dejan bastante que desear. A título de ejemplo, me referiré a algunas disposiciones que originan perplejidad.

\section{Las disposiciones sobre la atribución al secretario judicial de la potestad sobre la tramitación procesal}

Digamos que la primera piedra de esas disposiciones está constituida por el art. 456.2 LOPJ-reforma 2003, que establece una regla general de atribución de esa potestad al secretario judicial, limitable mediante reglas especiales que atribuyan al juez potestades sobre la tramitación en supuestos específicos. 
Desde que entró en vigor, esa disposición hubiera podido ser aplicada, aunque con un resultado predecible y alejado del objetivo perseguido por el legislador de la reforma. En efecto, las leyes procesales vigentes al entrar en vigor la LOPJ-reforma 2003 mencionaban, incluso en sus disposiciones relativas a tramitación, resoluciones del juez, del tribunal, sala o sección, o del presidente de éstas o del magistrado-ponente, de modo que lo que la LOPJ-reforma 2003 quería que fuera una especialidad -o una serie de ellas- acababa por ser casi la regla general.

Era razonable esperar que la ley $N^{\circ}$ 13/2009 iba a completar el art. 456.2 LOPJ-reforma 2003, y, previa consideración de las múltiples resoluciones de tramitación mencionadas en las leyes procesales, determinaría aquellas que, por razones de constitucionalidad o de política jurídica, quedaban reservadas a los titulares de los órganos jurisdiccionales.

Sorprendentemente, tanto el pre legislador, como, definitivamente, el legislador se descolgaron con la modificación de una larguísima serie de artículos de todas las leyes procesales con el único objetivo de hacerles expresar que la emisión de la resolución correspondía al secretario judicial. Eso, al menos en la medida en que la resolución mencionada en el artículo fuera una resolución sobre tramitación, era rigurosamente innecesario. En cambio, en la ley $N^{0} 13 / 2009$ no es fácilmente detectable ${ }^{42}$ la esperada y bien definida opción legislativa sobre las resoluciones de tramitación reservadas -a conciencia del contexto reformador- al titular del órgano jurisdiccional.

La técnica seguida por la ley $N^{\circ} 13 / 2009$ es, en consecuencia, una doble fuente de confusión:

$1^{\circ}$ ) Las resoluciones de tramitación que no han sido expresamente atribuidas al secretario judicial ¿deben ser dictadas por él en virtud de la cláusula general del art. 456.2 LOPJ-reforma 2003, o no deben serlo porque, al omitir mencionarlo expresamente, el legislador ordinario revela haber entendido que la resolución no es de tramitación?

$2^{\circ}$ ) La conservación de anteriores menciones legales de que el juez dictaría la resolución de tramitación en determinados supuestos ¿iha de ser entendida como opción legal por mantener esa atribución o como un descuido en el seguimiento de la técnica casuística que el reformador ha querido utilizar?

En definitiva, las confusiones apuntadas conducirán a errores sobre la titularidad de la potestad de resolver, a declaraciones de nulidad de oficio por exceso de poder del secretario judicial y a la aplicación de clases de impugnaciones no correspondientes al tipo de resolución debido según la ley.

${ }^{42}$ Salvo en específicos supuestos de resoluciones de inadmisión de la demanda o de inadmisión de actos de preparación de recursos, entre otros. 
2. Las disposiciones sobre la atribución al secretario judicial, en el proceso de ejecución, de potestades que exceden de la tramitación

En la materia del epígrafe encontramos, también, una combinación de normas como mínimo extraña desde la lógica jurídica. Me refiero al art. 456.3, a) LOPJ-reforma 2003.

Las potestades de tramitación no están afectadas por las normas de la disposición mencionada, porque, aunque se ejerciten en la ejecución, se someten al art. 456.1 y 2 LOPJ-reforma 2003 y pueden plantear los problemas interpretativos y de aplicación tratados en el apartado anterior.

Las normas ahora consideradas se refieren a potestades adicionales del secretario judicial en la ejecución, y su objetivo -como el del art. 456.1 y 2 LOPJ para su ámbito- es enmarcarlas mediante ley orgánica, dejando su ulterior precisión a las leyes procesales ordinarias.

Pues bien, ese objetivo se persigue de este sorprendente modo:

$1^{\circ}$ ) Es necesario que las leyes procesales prevean la atribución (art. 456.3 LOPJ-reforma 2003).

$2^{\circ}$ ) Podrán hacer esa previsión en determinadas materias, entre las que está la ejecución (art. 456.3, a) primer inciso LOPJ-reforma 2003).

$3^{\circ}$ ) Pero, para que el secretario judicial tenga la atribución, también es necesario que las leyes procesales no se la asignen al titular del órgano jurisdiccional (art. 456.3, a) inciso segundo LOPJ-reforma 2003).

En síntesis: primero es necesario que se le den atribuciones al secretario judicial, y, segundo, que no se le quiten, por atribución de las mismas al juez. Pienso que hubiera bastado con una buena definición normativa del supuesto de atribución (positiva) de la potestad, aunque concedo que tal vez sea eso lo que se persigue, enrevesadamente, con la referencia a posibles exclusiones expresas de la atribución.

Lo que ocurre es que, al especificar el legislador los supuestos de atribución de potestades en las leyes ordinarias, deja abiertas dudas importantes, incluso si el intérprete procura sujetarse a la lógica del art. 456.3, a) LOPJ-reforma 2003. Veamos algunos ejemplos:

$1^{\circ}$ ) Sabemos por el art. 551.3. $1^{\circ}$ y, sobre todo, por el art. 587 LEC, que el secretario judicial es competente para decretar el embargo de bienes del ejecutado, después de despachada la ejecución. A partir de ahí ¿cómo hay que entender que el art. 581 LEC -ejecución dineraria precedida de requerimiento de pago- disponga que "si no se pagase en el acto, el Tribunal procederá al embargo de sus bienes", y que el art. 608 LEC -supuesto especial de límite cuantitativo del embargo de salarios y pensiones- establezca que "el tribunal fijará la cantidad que puede ser embargada"? ¿Se trata de supuestos de la prevista norma especial de atribución de potestad al titular del órgano jurisdiccional o 
de un olvido de las consecuencias que derivan del art. 453.3, a) LOPJ-reforma 2003? Más aún ¿debe interpretarse "tribunal" como una referencia al secretario judicial orgánicamente relacionado con el tribunal?

$\left.2^{\circ}\right) \mathrm{Si}$, voluntariosamente, asumiéramos la última interpretación ¿cómo entender entonces que el art. 612, al regular la mejora, reducción y modificación del embargo, establezca, simultáneamente, que "el tribunal proveerá, mediante providencia, sobre estas peticiones según su criterio" (art. 612.1, pár. segundo LEC) y que "el secretario judicial resolverá mediante decreto sobre estas peticiones" (art. 612.2, LEC)?

$\left.3^{\circ}\right)$ El art. 551.3. ${ }^{\circ}$ LEC atribuye al secretario judicial la potestad de decretar "las medidas ejecutivas concretas que resultaren procedentes". Siendo así, hay varias disposiciones reguladoras de la ejecución no dineraria que arrojan dudas sobre si ciertas atribuciones que se hacen al "tribunal" son expresión de la regla especial o un error debido al olvido del art. 453.3, a) LOPJ-reforma 2003. No es el caso de los arts. 708 y 7009 LEC, que, al detallar que el tribunal resolverá "por medio de auto", no dejan duda sobre la atribución de la potestad. Pero sí que es el caso del art. 699 LEC que, en general para la ejecución por prestaciones no dinerarias, atribuye al tribunal el requerimiento con fijación de plazo -como lo hace para el supuesto más específico de la ejecución por prestaciones de hacer el art. 705 LEC-; si bien, sorprendentemente-porque no se intuyen las especiales razones- los arts. 704.1 y 707 LEC encomiendan al secretario judicial el requerimiento, con fijación de plazo.

\section{Las disposiciones sobre la impugnabilidad mediante recurso de revisión contra resoluciones del secretario judicial en el proceso de ejecución}

El defecto de técnica legislativa en esta materia se refiere a la regulación de las resoluciones del secretario judicial que son impugnables mediante el mal llamado recurso de revisión.

Para empezar, este medio de impugnación no es ni siquiera mencionado en el art. 562 LEC. No es excusa que ese artículo no sea el único que establece los medios de impugnación en la ejecución, sino que, p. ej., también lo hace el art. 563 LEC. Eso es cierto, pero, por un lado, el último es un supuesto especial respecto del art. 562 y, por otro, cuando se analiza el articulado de la LEC se concluye que el "recurso de revisión" está previsto en diversos supuestos para hacer valer la ilegalidad de la actividad ejecutiva. Tampoco es excusa que el "recurso de revisión" sólo sea admisible en supuestos legales específicos, porque lo mismo ocurre con el recurso de apelación, sin que ello impida nombrarlo en el art. $562.2^{\circ}$ LEC.

Una segunda observación se refiere al modo de establecer los supuestos en los que un decreto del secretario judicial sería impugnable mediante "recurso de revisión". 
El art. 551.5 LEC concede "recurso de revisión" directo contra el decreto que dicte el secretario judicial inmediatamente después del auto de despacho de ejecución, disponiendo medidas ejecutivas concretas y, entre ellas, en su caso, el embargo si fuera posible. Dos detalles quiero destacar: en primer lugar, que esa adopción de medidas depende del estado de los autos; en segundo lugar, que tan relevante es aquella referencia temporal que el art. 551.3 dispone que el decreto debe ser dictado el mismo día o en el siguiente hábil del dictado del auto.

Pues bien, he aquí la cuestión: si el estado de los autos -normalmente por la progresiva adquisición de información sobre el patrimonio del ejecutado o porque ocurren hechos procesalmente relevantes en el devenir de la ejecuciónno permite que todas las medidas sean adoptadas en ese decreto, sino en otro u otros posteriores ¿deberemos entender que la regla de impugnabilidad objetiva del art. 551.5 LEC ya no es aplicable a tales posteriores decretos, salvo que haya nuevas normas especiales que establezcan la procedencia del recurso? Sería un sinsentido: lo que justifica la impugnabilidad objetiva es el contenido de la resolución y no el momento procesal en el que se dicta.

Para acabar, la otra norma de alcance más general sobre impugnabilidad objetiva mediante "recurso de revisión" también es técnicamente desafortunada. Me refiero al art. 563.1, pár. segundo LEC. Su redacción incurre en un injustificado mimetismo con la regulación de la recurribilidad objetiva en apelación contra resoluciones del juez: que se haya resuelto en contradicción con el título ejecutivo. No digo que el "recurso de revisión" no esté justificado en ese supuesto. Lo que quiero hacer notar es que, no teniendo el secretario judicial potestad para valorar el título ejecutivo y despachar ejecución-porque es exclusiva del juez (art. 55.1 y 2 LEC) - el supuesto de recurribilidad hubiera debido incluir también la contradicción entre el decreto y el auto de despacho de ejecución. 